\title{
Alternative Dispute Resolution in the Digital Sector
}

\section{A Dejurisdictionalization Process?}

Rebecca Berto*

\section{Abstract}

Alternative Dispute Resolution (=ADR) is a generic reference to consensus-based processes that provide an alternative to litigation and to binding arbitration procedures. Analysing European provisions, the European legislator pushes Alternative Dispute Resolution methods as a means of resolving not only consumer-to-business disputes but also business-to-business. This may determine over the long term a sort of 'dejurisdictionalization' process, moving disputes from tribunals to Alternative Dispute Resolution methods. Procedural rights, however, such as raising interpretative questions to the European Court of Justice, may only be exercised before a court.

Therefore, Alternative Dispute Resolution and national civil procedure are separated by a sort of procedural 'Chinese wall': this legislator's forma mentis, repeated also in more recent directives, hinders the development of cross-border procedural provisions capable of tackling the legal and procedural questions posed by communication services and new technologies, such as blockchain, whose technical features are not limited by geographical boundaries.

This article argues that, in the light of technological advancements, the European internal market needs new common procedural legislation fit for the cross-border economic and legal relationships carried out within it.

Keywords: European legislation, Alternative Dispute Resolution, civil procedure.

\section{Introduction}

The Treaty on the Functioning of the European Union assigned the competence in civil procedures regarding cross-border cases to the European Union. Therefore, according to Article 81, the European Union shall develop judicial cooperation in civil matters having cross-border implications on the basis of the principle of mutual recognition of judgments and decision of extrajudicial cases.

* $\quad$ Rebecca Berto is a lawyer with ECC-Italy: d.jur. University of Padua, Pg. Dipl. International Dispute Resolution (Arbitration) Queen Mary University - London, admitted to the Italian Bar. The views expressed herein are solely the author's and represent neither that of ECC Italy nor of its host structures or any other of its public financiers. All opinions and errors are of the author. The author did not receive private or public funds for this article. 
This cooperation includes the adoption of measures for the harmonization of the laws and regulations of member states. In particular, the European Parliament and the Council shall adopt those instruments necessary for the proper functioning of the internal market. Two examples of these legal measures are the cross-border service of judicial and extrajudicial documents and the cooperation in taking evidence. ${ }^{1}$ Moreover, Article 81 (2) letters e) f) and g) of the Treaty on the Functioning of the European Union outlines three goals: an effective access to justice, the elimination of obstacles to the proper functioning of civil proceeding and the development of alternative methods of dispute settlement.

In order to achieve these goals, the European legislator has adopted a tripartite legislation strategy: the development of new procedural instruments, the regulation of specific sectors in order to reach procedural harmonization and the adoption of common standards with the aim to achieve a sort of horizontal harmonization.

The first group includes those procedural instruments that have a set of common provisions and its procedural law gaps, as for example nomination of experts, are filled by the civil procedure law of the single member state. These procedural tools are, for example, the European small claim procedure ${ }^{2}$ or the European payment order. ${ }^{3}$ The second group includes directives like the consumer Alternative Dispute Resolution directive (= consumer-ADR). ${ }^{4}$ Finally, the third legislative activity includes the directive on mediation. ${ }^{5}$

However, the availability of procedural tools, like the European small claim or the European payment order, do not appear to be enough to cope with the legal exigencies of the European internal market: the European small claim is available for claims whose value does not exceed EUR 5,000.00, while the European payment order allows creditors to recover uncontested civil and commercial credits. Even though both procedures have been simplified, the enforcement of a small claim sentence or of a payment order relies on the civil procedural norms of the enforcing member state.

At the same time, disputant parties can take recourse to Alternative Dispute Resolution methods instead of bringing the claim to court. Alternative Dispute Resolution methods are characterized by the disputant parties' voluntariness. This characteristic is present in every procedural stage of an Alternative Dispute Resolution procedure. Indeed, disputant parties are free to take part in the Alternative Dispute Resolution procedure. They are free to agree with the solution proposed by the Alternative Dispute Resolution body, and they are not legally obliged to comply with the accepted solution.

Despite these procedural tools, the internal market's legal and procedural barriers are resistant to being overcome. According to the European Commission, only $7 \%$ of small and medium businesses based in the European Union offer and 
sell their products or services across the European internal market. ${ }^{6}$ For this reason, in September 2016 the European Commission affirmed the indispensability of creating a digital single market strategy, the aim of which is to reduce barriers and stimulate business within the European internal market.

The reduction of barriers, however, should be addressed via new and innovative procedural laws. For example, an effective solution would be to consider Alternative Dispute Resolution mechanisms as a complementary means for courts and at the same time would build up procedural connections among courts by re-addressing disputant parties to tribunals for specific matters, such as to obtain precautionary measures or submit interpretative questions to the European Court of Justice or the Constitutional Court.

Therefore, this article argues that there is no real legal and procedural interaction between judicial systems and Alternative Dispute Resolution settlement because they are understood as procedurally separated by a sort of Chinese wall: tribunals are regulated by the procedural laws of each single member state, while Alternative Dispute Resolution is part of the private justice system and is a voluntary-based procedure.

However, this Chinese wall between Alternative Dispute Resolution and legal infrastructure may leave open a legal question that could be, otherwise, addressed. For example, if a provision does not comply with the Constitution of a state, is the Alternative Dispute Resolution body authorized not to apply this provision? Is there a procedure for re-addressing this issue to the Constitutional Court of a state? If an Alternative Dispute Resolution body has interpretative doubts over a European disposition, can it address the questions to the European Court of Justice? Actually no, because Alternative Dispute Resolution methods are not tribunals or courts as per the definition given in Article 267 of the Treaty on the Functioning of the European Union.. Moreover, there is no procedural provision that allows an Alternative Dispute Resolution body to address the interpretative question to a court or a tribunal.

Within this legal context, a technologically interconnected society that is looking at the employment of the Internet of things (IoT) or of artificial intelligence (AI) will need not only the development of alternative methods for the resolution of disputes but also a dynamic legal procedural system, overall, in order to cope with the needs of modern society.

This article begins by analysing the actual procedural relation between Alternative Dispute Resolution and the judicial system. The second part analyses the most recent provisions on Alternative Dispute Resolution included in a directive addressed to the communications and digital sector, such as the European Electronic Communication Code, the directive on copyright and other recent rules. From these provisions, the Alternative Dispute Resolution methods addressed in the European directives have different procedural flows because the

6 European Commission, 'A Digital Single Market in Europe - Bringing down Barriers to Unlock Online Opportunities', Bruxelles, 2016, p. 6, available at A digital single market in Europe Publications Office of the EU (europa.eu), last accessed on 28 November 2020. 
directives do not outline the details of the Alternative Dispute Resolution's procedure, leaving room for national provisions.

The importance of a procedure should not be underestimated: it should not be forgotten that the aim of laws and procedures is to regulate economic, commercial and human relationships, providing legal certainty over these relations through a complex system of rights, duties and procedures.

This article concludes that it is time to pay attention to civil procedures, in order to create a dynamic legal procedural system that is able to cope with this society's technological, economic and commercial advancements.

\section{Procedural Relationship Between Tribunals and the Alternative Dispute Resolution Method}

Traditionally, one duty of a state is to build up a legal infrastructure that should fulfil three requirements: efficiency, quickness availability to the public at an affordable cost. In parallel to the state's judicial system, disputant parties may take advantage of private justice systems: international arbitration, mediation, conciliation or adjudication are only a few examples of Alternative Dispute Resolution methods.

In analysing the European provisions from 2005 to 2011, it emerges that European legislators have focused their attention on specific regulated sectors, such as energy, ${ }^{7}$ consumer credit ${ }^{8}$ or payment services. ${ }^{9}$ Alternative Dispute Resolution (=ADR) was thought up as a tool to settle disputes that involved users: the underlying idea was to discourage from litigating small claims by introducing a principle of proportionality, according to which litigating costs should be ideally lower than the amount being disputed. These European directives required every single member state to designate a competent independent authority called to ensure effective compliance with the directives and provide an effective Alternative Dispute Resolution procedure for the settlement of disputes. Moreover, the traders active in the mentioned sectors should adhere to an adequate and effective Alternative Dispute Resolution method.

In 2011, the European Parliament approved a resolution ${ }^{10}$ in order to encourage the employment of Alternative Dispute Resolution methods, not only in relation to consumer-to-business disputes but also in business-to-business relationships and more generally in commercial transactions, irrespective of whether they are carried out between private or public undertakings; family disputes; defamation cases and other general interest disputes or ones involving parties with different legal statuses. In the same resolution, the European

7 Directive on internal market on Electricity (EU) 2009/72 and Directive on internal market on natural gas (EU) 2009/73.

8 Directive on credit agreement for consumers (EU) 2008/48, amended by Directive (EU) 2014/17.

9 Directive on payment services 2 (EU) 2015/2366 Art. 99-102.

10 European Parliament Resolution on alternative dispute resolution in civil, commercial and family matters, Procedure 2011/2117 available at www.europarl.europa.eu/doceo/document/ TA-7-2011-0449_EN.html?redirect, last accessed on 22 November 2020. 
Parliament stressed three relevant points. First, it took the European directive on mediation, (EU) 2008/52, as an example of a legal framework providing common standards for any Alternative Dispute Resolution body based in a member state of the European Union. Second, the access to justice should not be prejudiced, so Alternative Dispute Resolution instruments should remain an alternative available to the parties, whereby disputant parties are not bound by the solution proposed by the Alternative Dispute Resolution body. Finally, contractual clauses regarding Alternative Dispute Resolution or similar provisions contained in contractual general terms should not prejudice or hinder access to justice.

After 2011, dispositions on Alternative Dispute Resolution were included in Directive (EU) 2012/34 (Art. 46), Regulation (EU) 2012/531 (Art. 17), the directive on package travel, ${ }^{11}$ among others, in order to encourage the settlement of consumer-to-business complaints out of court. With specific reference to consumer disputes, European legislation also introduced the ADR-consumer through Directive (EU) 2013/11, which provides a set of minimum guarantees and procedural standards. Therefore, according to Recital 31, the ADR should perform its task fairly, practically and proportionally to both disputant parties. The consumer-ADR directive, from Article 6 to Article 10, provides rules on the independence and impartiality of the persons in charge of the consumer-ADR; the procedure should be carried out fairly, which means, for example, that the disputant parties should be in a condition to express their comments over arguments, evidence, documents, facts put forward by the other party. Furthermore, disputant parties should be notified on the outcome of the ADR procedure and receive a statement of the reasons on which the outcome is based. However, most important is Article 9 (2) of Directive (EU) 2013/11, which reads as follows:

(b) The parties, before agreeing or following a proposed solution, are informed that (i) they have a choice as to whether or not to agree to, or follow, the proposed solution; (ii) participation in the procedure does not preclude the possibility of seeking redress through court proceedings; (iii) the proposed solution may be different from an outcome determined by a court applying legal rules [...] (d) The parties, before expressing their consent to a proposed solution or amicable agreement, are allowed a reasonable period of time to reflect.

Accordingly, the disputant parties are free to adhere to the consumer-ADR decision and are not legally obliged to implement it. In this latter scenario, the other party has no other choice than to go to court: if the dispute's value does not exceed EUR 5,000.00, the party can take advantage of a European small claim procedure. Above this value, the party can only rely on the ordinary national means and procedures.

It appears evident that the European legislation has tried to push Alternative Dispute Resolution as a settlement mechanism for disputes. Therefore, ADRs are 
also mentioned as a mechanism for resolving disputes in Directive (EU) 2019/633 regarding unfair trading in business-to-business relationships in the agricultural and food supply chain. After having recalled the provisions on unfair commercial practices, which should be ascertained by the member state's independent authority or by the courts because it could be an infringement of competition laws, as for example in Germany, European legislation advances the suggestion to submit this issue to an Alternative Dispute Resolution mechanism. However, there are no norms on the procedure of this Alternative Dispute Resolution method. Similar considerations may be put forward for another Directive, (EU) 2018/2001, which in Article 16 (5) foresees the possibility for member states to introduce Alternative Dispute Resolution methods for issues concerning the concession of solar energy. However, concessions are usually given by city councils or other public entities and are regulated by administrative laws. This would mean introducing an ADR in administrative procedures. This is another example where European legislation asks the national legislator to choose to take advantage of this rule by introducing an ADR. At the same time, the national legislator is called to dictate rules on this ADR and on its role within the national administrative procedures.

What emerges from this more recent trend is a sort of 'dejurisdictionalization' process, that is, the idea to take disputes out of the courts in favour of Alternative Dispute Resolution methods, which may be settled also by independent regulatory authorities. The underlying reason is not only to discourage bringing small claims to court but also to settle disputes out of court when the disputes concern specific law sectors. In the latter case, the reason to move away from courts appears to be as an attempt to reduce the workload of tribunals. Judges of national tribunals or courts are bound by the rigidity of national procedures, so the parties and the judge have little room, even with the parties' agreement, to move outside the strictures of civil procedure. Moreover, judges do not necessarily have the required knowledge in very specific sectors.

On the contrary, independent regulatory authorities have knowledge of specific law sectors, such as telecommunications. However, independent regulatory authorities are administrative entities provided with specific technical qualifications in order to exercise control and regulation functions in sensitive or highly technical sectors, where the protection of different and sometimes conflicting interests requires an equidistant administrative action. The action of these authorities is independent from the government's action in order to grant autonomy and impartiality concerning the interest involved. Because independent authorities are administrative entities, they are not empowered to verify the compliance of laws with the Constitution or to ask the European Court of Justice for a common interpretation; these are still prerogatives of the judicial power.

Within this context, it should be remembered that the scope of a civil procedure is to implement the rights of the parties to be heard by a court and to get a regulation or composition of the dispute according to law. Courts also have the duty to verify the compliance of laws with constitutional norms and to ask the European Court of Justice to clear up the interpretation and validity of a 
European law. The intervention of the European Court of Justice or of the national Constitutional Court is foreseen by procedural rules, whose requirements must be met and checked by the judges of the lower courts before the issue is submitted to the higher court.

Considering these aspects, instead of keeping Alternative Dispute Resolution procedures and tribunals separate, the complementary role of Alternative Dispute Resolution methods should be improved by providing procedural rules that would allow an Alternative Dispute Resolution body to redress the parties to court in order to get precautionary measures or raise interpretative questions to the superior courts.

Actually, there is no procedural relationship between Alternative Dispute Resolution bodies and courts - only mediation, as a form of ADR. Indeed, courts and ADR relate in three instances: cost sanctions, mediation ordered by a court or mandatory mediation provided by laws.

Cost penalties are employed to promote the use of an Alternative Dispute Resolution method in the course of proceedings. However, even if a party prefers its case decided by a court instead of by mediation, for example, and this choice appears to be unreasonable, cost penalties are not automatically applied, because it is a factor that a court takes into account when exercising its cost discretion. Indeed, a judge should consider the peculiarities of the case, for example, the lawyer's evaluation that a mediation had no realistic prospect of succeeding and would simply add costs, or the case is unsuitable for an alternative dispute settlement mechanism because it raises quite complex legal questions. ${ }^{12}$

Compulsory mediation, as a necessary procedural step before a formal proceeding in front of tribunals, is limited in Austria to neighbour disputes and, in particular, categories of employment disputes, which include disability complaints and termination of apprenticeships. ${ }^{13}$

In Italy, a law on mediation has been introduced by Legislative Decree Number 28 of 2010. This law on mediation shows procedural peculiarities: as in other legislations, mediation is a procedural step before commencing a court's proceedings or may be ordered by a judge during a proceeding before a court. Therefore, a judge can refer the parties to out-of-court mediation, but the parties are not compelled to reach an outcome. Indeed, the parties are allowed to end the mediation at the preliminary meeting and continue with the court's procedure. It is a sort of opting-out rule. Another interesting point of the Italian law on mediation is its Article 5 (3), according to which, during mediation, access to court is granted in order to obtain protective or interim relief measures.

The Italian law on mediation is an example of a first step taken in order to build up a procedural interconnection between Alternative Dispute Resolution and court procedure, keeping the procedural difference between them: the connection between the two procedures relates to specific procedural matters, such as seeking protective measures.

13 G. De Palo and M.B. Trevor, EU Mediation: Law and Practice, Oxford University Press, 2012, Paras. 2.22-2.24. 
This procedural interrelation would strengthen the citizens' and businesses' fundamental and constitutional rights by granting them access to justice, which is one scope of Article 81 of the Treaty on the Functioning of the European Union. At the same time, it would allow to tackle the challenges posed by the digital sectors and by the economy that are not bound by geographical boundaries. In this sense, disputant parties can avail themselves of an Alternative Dispute Resolution method because it better meets their needs and is more flexible, procedurally speaking, while being assured that in specific matters they may be re-addressed to a court without opting out from the Alternative Dispute Resolution procedure.

\section{Alternative Dispute Resolution and the Directive on Copyright}

Having set the scene, it is time to review the European provision on digital services, technologies and communications services with a closer look at the Alternative Dispute Resolution norms.

The European legislators have issued four directives that involve communication services and other operators of the digital markets. At the same time, the European legislator is aware about further technological improvements, such as the Internet-of-the-things: it has tackled the issues concerning goods and services which do not work because of copyright infringement. Two of these directives - the one on copyright, Directive (EU) 2019/790, and the European Electronic Communications Code, Directive (EU) 2018/1972 - also provide rules regarding Alternative Dispute Resolution. The last two - Directive (EU) 2019/770 and Directive (EU) 2019/771 - are designed to regulate other aspects, such as digital contents and sales of goods and services connected to the Internet.

The directive on copyright deploys tools to resolve copyright disputes. Article 17 (9) foresees different models that depend on the subject matter of the dispute and on whether the complainant is a user or a rightsholder.

In analysing the whole procedure outlined by the European legislator, as a first step, service providers will provide users of online content-sharing services a complaint procedure and a redress mechanism. The complaint procedure will be made available to users of online content-sharing service providers when the dispute concerns the disabling of access to or the removal of works or other subject matter uploaded by them. Even if subject to interpretative doubts, cloud services, which provide space not only for uploading content but also for sharing it, should probably comply and bring into existence a complaint procedure.

If the complaint is lodged by a rightsholder, it should expressly mention the underlying reasons for submitting the complaint. The service provider should examine the issue without delay. If the decision to disable access or to remove the uploaded content does not satisfy the user or the rightsholder, they can request a review, which should be carried out by an individual. This implies that in the first stage of the complaint procedure, an algorithm or AI may be employed for evaluating the complaint. 
Furthermore, according to Article 17 (9) of Directive (EU) 2019/790, member states shall ensure an out-of-court redress mechanism in order to settle disputes. This out-of-court mechanism should be impartial and not deprive the user of the legal protection afforded by national law. This shall not prejudice the user's right to take advantage of judicial remedies. Finally, member states shall also ensure access to a court or to another relevant judicial authority to assert the application of an exception or a limitation to copyright and related rights.

Generally speaking, Article 17 (9) leaves member states with the burden of dictating rules on three fundamental points. First, Member States are called to ensure that service providers adopt an effective complaint procedure and redress mechanism. In reality, this would mean that member states are called to foresee an independent authority made to control whether providers comply with this requirement and, in case of non-compliance, penalties should be foreseen at the national level. However, the powers of an independent authority are limited by geographical boundaries: without an objective link to the national territory, such as legal seat, registration of the domain or similar, it does not have the legal power to take action.

Second, member states are called to put in place an Alternative Dispute Resolution mechanism. Because there is no outline of a procedure or the recall of an existing ADR, such as mediation, it is not clear, however, what kind of procedure the European legislator has in mind. There is no mention as to whether a trader should take part in an out-of-court procedure, there is no objective requirement that ensures the impartiality of this $\mathrm{ADR}$ and there is no mention of an enforcement tool for ADR settlement reached and agreed by the parties. Moreover, there is no specific provision linking this out-of-court mechanism to courts, which can provide precautionary or relief measures during the Alternative Dispute Resolution procedure or a specific procedural rule, in order to acquire the intervention of the European Court of Justice.

The European legislator has adopted the safeguard provision, Article 17 (9), by which the parties' right to bring a claim to court is not prejudiced. Once again there emerges the procedural 'Chinese wall' that strictly distinguishes the Alternative Dispute Resolution procedure from courts and tribunals because the claimant can ask a court to issue an interim or other precautionary measure.

Third, member states should ensure recourse to judicial authority. The idea of linking a copyright complaint arising from the employment of cross-border technological tools, often present only in virtual space, to geographical boundaries has been adopted. For example, the peculiarity of cloud computing is that of being a flexible remote computing approach that can be done or accessed through the Internet as opposed to a personal computer or local server. ${ }^{14}$ As the cloud service can be accessed anywhere, it is location-less. ${ }^{15}$ Within this context, the determination of the competent tribunal is fundamental because on this legal

14 M. Nelson, 'The Cloud, The Crowd and Public Policy', Issues in Science and Technology, 2009, 25(4) p. 71.

15 P.T. Jaeger, J. Lin, J.M. Grimes \& S.N. Simmons, 'Where is the Cloud? Geography, Economics, Environment, and Jurisdiction in Cloud Computing', First Monday, 2009, 14, p. 6. 
issue depends also to which tribunal a request for precautionary measures should be addressed. For example, cloud services are location-less, so the only objective criterion that can be assumed is the legal seat of the provider or the residence of the user/rightsholder or the location of the device on which the content is recalled. If a competent court outside the European Union has been foreseen in the general terms agreed to by both parties, European provisions are not applicable.

Moreover, service providers are used to drafting contractual clauses on applicable law and jurisdiction. A study carried out in $2012^{16}$ on cloud services came to the result that cloud service providers include in their general terms clauses on applicable law, which is that of the United States or that of California.

As regards Alternative Dispute Resolution, the directive on copyright provides only a few rules about ADR and court procedures. This leaves room for national legislators, who can fill in the gaps, determining at worst 27 different ADRs and ADR procedures called to settle the disputes.

Finally, a point that should not be underestimated is that the copyright directive should be considered as a 'piece' of a broader legislation, whose purpose is to provide rules on digital content and services via Directive (EU) 2019/770 and to lay down rules on the sale of goods and services with digital elements via Directive (EU) 2019/771.

It is not the aim of this article to analyse both directives in depth. It is worth mentioning, though, that Directive (EU) 2019/770 is not applicable to electronic communications services as defined by Article 4 of the European Electronic Communication Code (EECC). Its Article 3 (9) rules, however, that "this Directive shall be without prejudice to Union and national law on copyright and related rights".

A similar provision is also foreseen by Article 9 of Directive (EU) 771/2019, which reads as follows:

Where a restriction resulting from a violation of any right of a third party, in particular intellectual property rights, prevents or limits the use of the goods in accordance with Articles 6 and 7, Member States shall ensure that the consumer is entitled to the remedies for lack of conformity provided for in Article 13, unless national law provides for the nullity or rescission of the sales contract in such cases.

Both provisions take the consumers' point of view and consider the matter of questioning when goods and services cannot work because of a copyright infringement. Only producers or service providers are aware if goods have sensors or other elements that allow to connect to the Internet and potentially create an IoT environment. The supply chain may be unaware about copyright

16 S. Bradshaw, C. Millard and I. Walden, 'Contracts for the Cloud: Comparison and Analysis of the Terms and Conditions of Cloud Computing Services', International Journal of Law and Information Technology, 2010, 19(3), pp. 187-223. 
infringement of the goods and services sold to users. A natural consequence of these norms will be the rise of disputes between the supply chain and producers.

On the other hand, neither Directive (EU) 771/2019 nor Directive (EU) $770 / 2019$ considers how IoT works. It is true that there is no single definition of IoT, but the Internet Society employs the term where network connectivity and computing capability extend to objects, sensors and everyday items, allowing these devices to collect and exchange data with minimal human intervention. ${ }^{17}$ Network connectivity is the foundation on which IoT operates. For example, in a domestic environment, where the domestic appliances are connected to the Internet and their information is collected and shared on a cloud service, a new process may be developed and created. Who is the copyright owner? The owner of the domestic environment, who put the appliances together in the same room? Or the cloud service provider, who shared the information sent by the different appliances? Or the producer of the single good?

There is no doubt that the increase of connectivity, coupled with the involvement of new market players in the communications sector, will probably lead to future patent wars. ${ }^{18}$

Within this context, the provision on Alternative Dispute Resolution mechanisms laid down in the copyright directive is not specifically addressed to cope with a fast-changing reality, leaving room for smart national legislators called to fill in the procedural gaps. This will determine procedural fragmentation within the European internal market.

\section{Alternative Dispute Resolution and the European Electronic Communications Code: Procedural Issues}

Unlike the copyright directive, the European Electronic Communications Code provides rules on Alternative Dispute Resolution for businesses and for consumers. Directive (EU) 1972/2018 should be transposed into national law by December 2020: at the time of writing the Italian Parliament is still examining the national law, which transposed this directive. This directive provides updated rules for traditional mobile and fixed telecommunication services and for new online communications providers. The European Electronic Communications Code will also cover services provided over the Internet, such as messaging apps and emails, which are also known as over-the-top services. The scope of this directive is to drive investment in $5 G$ and new fibre networks by creating a common legal framework between telecommunications companies and over-thetop providers.

17 Internet Society, 'The Internet of Things. An Internet Society Public Policy Briefing', 2017, available at www.internetsociety.org/wp-content/uploads/2017/09/ISOC-PolicyBrief-IoT.pdf, last accessed on 25 October 2020.

18 S. Pepe, K.J. Post \& L.W. Shapiro, 'Internet of Things: Next Patent War Zone', 2018, available at https://biglawbusiness.com/internet-of-things-next-patent-war-zone/, last accessed on 25 October 2020 . 
As regards Alternative Dispute Resolution, the European Electronic Communications Code distinguishes between consumer-to-business disputes and business-to-business disputes: the former kind are addressed by Article 25, while the latter by Article 26-27. Moreover, disputes concerning the radio spectrum are not subject to an outlined Alternative Dispute Resolution procedure (Art. 28); cross-border matters are resolved through a coordination of member states, which may request the Radio Spectrum Policy Group (RSPG), an advisory group that assists the European Commission, to use its good offices to address any problem or dispute in relation to cross-border coordination or cross-border harmful interference. Where appropriate, the RSPG may issue an opinion proposing a coordinated solution regarding such a problem or dispute (Art. 28 (3)).

Disputes between consumers and their suppliers arising under the directive or arising under the underlying agreements are regulated by Article 25 of Directive (EU) 1972/2018. According to this provision, member states should include the national regulatory authority in the list of Alternative Dispute Resolution entities. National regulatory authorities are competent to verify whether traders comply with the information duties as provided in Article 5-6 of Directive (EU) 11/2013, as recalled by Article 102 of the European Electronic Communications Code. The national authority should comply with Articles 6 to 12 of the consumer-ADR directive. Every single member state can also decide to designate another competent authority to deal with this kind of dispute. In other words, Article 25 (1) assumes that consumer-to-business may have a national character, that is, both disputant parties are based in the same member state.

However, procedural problems do arise when the consumer-to-business dispute has a cross-border nature and involves parties based in different member states. If no authority and ADR-consumer is competent, Article 25 (2) foresees the coordination of member states in order to settle the dispute.

This last rule leaves open procedural questions regarding the determination of the ADR of competence, in case of cross-border disputes, and there is no procedural provision in order to bring preliminary rulings to the European Court of Justice.

On the first point, even if no disposition is available on how to determine the competent national authority, it may be assumed that the competent authority is the one where the trader is based. This outcome is due to the systematic reading of the European Electronic Communications Code and Article 6 lett. $t$ of Directive (EU) 83/2011, according to which traders should inform consumers about the competent $\mathrm{ADR}$ and competent regulatory authority. This systematic interpretation of the consumer-ADR, along with other directives providing for Alternative Dispute Resolution, is strengthened by Recital 19 of Directive (EU) 2013/11, which reads as follows: “[...] This Directive is intended to apply horizontally to all types of ADR procedures, including to ADR procedures covered by Directive 2008/52/EC". Therefore, a systematic interpretation of the European provision leads to the application of the strongest safeguards foreseen by consumer protection laws. This interpretation will comply with Article 114 (3) of the Treaty on the Functioning of the European Union, according to which the 
Commission, in proposals concerning health, safety, environmental protection and consumer protection, will take as base a high level of protection, taking into account in particular any new development based on scientific facts.

However, if a trader does not comply with the rule of informing consumers about the competent $\mathrm{ADR}$ and regulatory authority, procedurally speaking, the consumer-ADR directive does not provide rules on determining the competence of an ADR, when two or more ADRs may potentially deal with the disputes. This point is left open. Furthermore, if no authority or consumer-ADR is competent, it is not clear how the member states should coordinate themselves to reach a solution of the dispute, there being no mention of a competent office or about the procedures to be followed. Being a cross-border issue, it is fundamental that procedural rules be outlined before a dispute arises and are common between member states, in order to grant the parties their right to present the case, the argument and the proof in support of their arguments.

On the second point, there is no procedural provision for bringing preliminary rulings to the European Court of Justice, which is competent in providing interpretation about the European laws. Indeed, regulatory or independent authorities are not equivalent to courts as per the meaning given in Article 267 of the Treaty on the Functioning of the European Union (TFEU), according to which only a tribunal or a court can refer the interpretative question to the European Court of Justice.

On the other hand, the dispute resolution procedure for business-to-business controversy presents procedural peculiarities that are regulated by Article 26-27 of (EU) 1972/2018. These rules are centred on the role of the national regulatory authority, which should provide a binding decision within four months, and on Berec, a European authority established by the European Directive 1979/2018. One key function of Berec is to encourage the consistent and better implementation of the regulatory framework for electronic communications.

In this procedure, member states have room to rule on two specific procedural points: the introduction of a specific Alternative Dispute Resolution mechanism and the institution of an appellate body, not necessarily a court, to which a party can submit an appeal against the decision taken by the national regulatory authority.

As regards the former procedural point, the legislator of every member state can establish a sort of option-out provision, according to which the regulatory authority can decline to deal with the dispute when other Alternative Dispute Resolution mechanisms are available. If the Alternative Dispute Resolution entity does not provide a decision within four months and the parties do not bring the issue to the courts, a party can request the intervention of the national regulatory authority, which should provide a decision within four months.

The reference to an alternative dispute settlement, made by the European directive, is vague because every legislator can rely on mediation or decide for a completely different ADR, defining its procedure.

The latter procedural aspect concerns the introduction of an appellate body, not necessarily a court, which is called to decide over the appeal lodged by the unsatisfied party. Therefore, Article 31 (2) reads as follows: 
[W]here the appellate body referred to in paragraph 1 of this article is not judicial in character, it shall provide reasons for its decision, which shall be subject to the review of a court or a tribunal within the meaning of art. 267 TFEU.

This provision leaves room for national legislators to dictate the appeal's procedural norms. Indeed, this body should be independent from the parties involved and from any external intervention or political pressure. The only express requirement posed by the norm is that its members have the appropriate expertise. This would mean to shift to a national legislator the duty to provide rules in order to strengthen the independence of the appellate body members; disposition on conflict of interest, disclosure of relevant information that may impair the member's independence and rules on member recusation are just a few examples of this topic.

Article 31 (1) addresses one specific issue: a member state must ensure that the merits of the case are duly taken into account. This implies the reexamination of fact findings and the correction of error in laws by this appellate body. Furthermore, the appellate body must provide reasons for its decision. Against the appellate body decision, the unsatisfied party may submit an appeal to a court or a tribunal within the meaning of Article 267 of the TFEU.

The second procedural peculiarity in business-to-business disputes is the interpretative power in head of Berec, which is an administrative Authority, regulated by the European Regulation (EU) 2018/1971. Theoretically speaking, providing an administrative Authority with interpretative powers, may have the positive effect of increasing the predictability of the application of the law by national authorities since the effects of a decision issued by national authorities are limited to a single case and bind only the parties involved.

However, the exercise of this interpretative power has a critical side: first, the line between interpretation and amendments ultra vires is thin because amendments ultra vires add words to the directive rules. Second, Berec is not properly bound to a literal interpretation, but may and should interpret the rules of the European Electronic Communications Code in light of the scope of the directive. Article 27 expressly provides that Berec's opinion should be taken foremost into account by the national regulatory authority in resolving the dispute. This may become an arguable and tricky point because one fundamental legal principle is the principle for non-retroactivity, according to which rules should apply to future actions.

The thorough reading of the European Electronic Communications Code and the disposition on dispute settlement shows that there is no express rule on time limitation about Berec's opinion. The national authority may take into account in its decision Berec's opinion. National authorities, acting as alternative dispute settlement entities, should decide in accordance with their procedure and act as an impartial authority and should grant to the disputant parties their right to present their case and arguments, following the principle of fair and equitable treatment of the parties. 
For these reasons, the interpretation itself rendered by Berec should be clear and Berec's interpretative powers should be exercised in such a manner as not to breach the principle of non-retroactivity, which occurs when the effect of the interpretation is an amendment of the law rather than an interpretation that clears up the meaning of the provisions.

The difference between an interpretation and an amendment will certainly become a tricky point, over which the European Court of Justice may be called to issue an interpretative decision.

\section{Conclusion}

Over 40 years ago, Mauro Cappelletti warned about the gap between civil justice and the complexity of contemporary societies that demands new methods of dispute resolution because the traditional means of redress are increasingly insufficient in addressing the challenges of society. ${ }^{19}$

This warning is a topical issue because technological advancements and connectivity require a legislator to adjust existing regulation, in order to provide a procedural legal framework that is beneficial to the increasingly cross-border and international nature of commercial relations.

The legislative strategy of European legislation with the provisions addressed to regulate the digital and communications sector is to create common standards between member states. Minimum common standard does not automatically imply the creation of a common legal framework capable of regulating the arising disputes and in the long term encouraging cross-border commerce within the European internal market.

The consequences of this choice are double. On the one hand, European legislation keeps the traditional idea of a separation between Alternative Dispute Resolution procedures and proceeding before courts.

On the other hand, the encouragement to employ Alternative Dispute Resolution methods increases a sort of 'dejurisdictionalization' process, moving disputes from courts to Alternative Dispute Resolution methods. Over the years, the underlying reason is no longer connected with the intent to reduce the tribunals' workload, but rather to involve independent and regulatory authorities in the resolution of disputes in specific and technical sectors. Independent authorities are called to resolve disputes in specific law subjects and, like Berec, are legally entitled to provide interpretative opinions over European norms applicable to the dispute. This may be an advantage if the authority's power is limited to clearing up the meaning of the provisions. It becomes a disadvantage when the interpretation is not clear and may affect the disputant parties' procedural rights.

Within this context it should not be forgotten that laws, which respond to the society's challenges, are subject to scrutiny regarding their coherence and

19 M. Cappelletti, 'Une revolution en cours dans le droit judiciaire civile', 1975, Revue Internationale de droit comparé, pp. 571-597. 
compliance with the hierarchically superior basic rules. It is a well-known fact that Constitutional Courts have the legal duty to check the coherence and compliance of laws with constitutional laws. This point is of extreme importance because it preserves and grants those fundamental laws and legal principles, which should remain immune from the temporary caprices of any currently governing administration. Only courts have the prerogative to verify the compliance of laws with the Constitution or to ask for a common interpretation from the European Court of Justice.

Actually, this strict separation between the alternative dispute procedure and tribunal proceedings requires a party to bring a claim to court, in order to get interim measures, precautionary measures or to exercise other rights foreseen by the Constitution.

A successful Alternative Dispute Resolution system that keeps a close eye on the technological and economic development of modern society should experience new procedural rules that are suitable to tackle the challenges posed by cross-border disputes. In this sense, an Alternative Dispute Resolution system applied also to other fields of law, such as consumer-to-business disputes, should foresee means of redress to courts for all those rights that are the prerogative of tribunals. In this way, the aim of granting access to justice becomes stronger and at the same time the citizens' and businesses' right of defence is strengthened. 